\title{
The differentiation of asaccharolytic anaerobic gram- positive cocci by protein electrophoresis
}

\author{
E. A. TAYLOR*, P. J. H. JACKMAN $†$ and I. PHILLIPS $\ddagger$
}

Division of Microbiology, and TDepartment of Microbiology of the Institute of Dermatology, UMDS, St Thomas's Campus, London SE1 7EH

\begin{abstract}
Summary. Conventional biochemical and antibiotic sensitivity tests were used to allocate 87 clinical isolates of anaerobic gram-positive cocci to currently recognised species, in comparison with type and other authentic reference strains. Whole-cell protein electrophoresis was then performed with extracts of each strain. Allowing for difficulties of standardisation, it was possible to allocate most of the organisms to species-related groups on the basis of protein patterns. Organisms identified conventionally as Peptostreptococcus anaerobius and $\boldsymbol{P}$. micros formed homogeneous groups by protein electrophoresis. There was evidence for heterogeneity amongst strains identified as $P$. asaccharolyticus (two groups, including $P$. indolicus), $P$. prevotii and $P$. magnus. However, aberrant $P$. prevotii strains were allocated to the $P$. asaccharolyticus groups, leaving a homogeneous $P$. prevotii group, and if $P$. variabilis were re-instated as a species, the remaining $P$. magnus strains could be divided into two groups. Of the anaerobic gram-positive cocci in the National Collection of Type Cultures deposited by Hare, Group IV is $P$. magnus, Group IX is $P$. micros and Groups I, III and VIII appear to be related to the butyrate-producing species $P$. asaccharolyticus and $P$. prevotii, but are strongly saccharolytic.
\end{abstract}

\section{Introduction}

The taxonomy of the anaerobic gram-positive cocci is still in a state of evolution. There have been major changes in the last two editions of Bergey's Manual, from the scheme described by Rogosa ${ }^{1}$ to that now proposed by Holdeman Moore et $a l^{2}$ for peptococci and peptostreptococci, and by $\mathrm{Hardie}^{3}$ for anaerobic streptococci. The changes are largely based on more extensive biochemical studies and determination of $\mathrm{G}+\mathrm{C}$ contents of DNA, and to a certain extent on DNA-DNA homology studies ${ }^{4,5}$ supported by analysis of the structure of mucopeptide. ${ }^{6}$ Although some species are now well established, others are conceded to be heterogeneous. ${ }^{2}$

Schemes for the identification of these organisms have been limited by the changes in taxonomy and by the fact that anaerobic cocci from clinical material are usually unreactive, especially in tests for carbohydrate fermentation. Recently-introduced commercial kits have included a wider variety of biochemical tests, and species differentiation has improved, but there are still problems, as, for example, with the differentia-

Received 13 March 1990; revised version accepted 1 Oct. 1990 *Present address: Roussel Laboratories Ltd, Broadwater Park, North Orbital Road, Denham, Uxbridge, Middlesex UB9 5HP. +Present address: National Collection of Yeast Cultures, AFRC Institute of Food Research, Colney Lane, Norwich NR4 7UA.

¥Correspondence should be sent to Professor I. Phillips, Department of Microbiology, St Thomas' Hospital, Lambeth Palace Road, London SE1 7EH. tion of the indole-negative, butyrate-producing cocci, ${ }^{7}$ complete failure to identify an important minority of strains, ${ }^{8}$ and a lack of an independent and authoritative identification of the clinical strains used in such systems.

Numerical taxonomy based on patterns of wholecell proteins separated by polyacrylamide gel electrophoresis is a recognised tool in microbial systematics. ${ }^{9,10}$ Cato et al..$^{11}$ demonstrated distinct differences in the patterns obtained with anaerobic cocci and were able to distinguish Peptostreptococcus micros from the then Peptococcus magnus, a distinction previously based largely on cell size. They suggested that the technique might be valuable for identification as well as in taxonomy.

The present study was designed to assess the usefulness of whole-cell protein electrophoretic patterns in the identification of asaccharolytic grampositive cocci commonly associated with human disease.

\section{Materials and methods .}

\section{Reference strains}

The reference strains that were used are listed in table I. Recognised saccharolytic species were included to study the relatedness of the asaccharolytic and saccharolytic species and of the anaerobic grampositive cocci lodged in the National Collection of 
Type Cultures (NCTC) as the Hare Groups, many of which were reported to be saccharolytic by Hare. ${ }^{12}$ Members of Hare Group VIa and VIIb proved to be micro-aerophilic on re-examination; therefore, they were not included in this study. Similarly, members of Hare Group V were excluded, as the representative strains were found to be gram-negative.

\section{Clinical strains}

A collection of anaerobic gram-positive cocci, isolated from various clinical specimens examined in the Department of Microbiology, St Thomas' Hospital, London was also included. Strains were selected to include organisms originating from skin ( 27 strains), faeces (16), urogenital (27) and oral (17) specimens. Great care was taken to select single colonies for subculture to ensure purity.

\section{Storage and maintenance}

During the investigation, strains were maintained on non-selective blood-agar plates, subcultured at 48-h intervals and incubated anaerobically at $37^{\circ} \mathrm{C}$. A modification of the method of Feltham et al. ${ }^{13}$ was used for long-term storage of all organisms at $-70^{\circ} \mathrm{C}$ in a medium containing sterile defibrinated horse blood $10 \%$ and sterile glycerin $5 \%$ in thioglycollate broth (Oxoid CM23).

\section{Incubation}

All cultures were incubated in a mixture of $\mathrm{N}_{2} 80 \%$, $\mathrm{CO}_{2} 10 \%, \mathrm{H}_{2} 10 \%$ in an anaerobic chamber at $37^{\circ} \mathrm{C}$.

\section{Conventional identification of clinical isolates}

Antibiotic susceptibility tests, selected from those recommended by Sutter and Finegold, ${ }^{14}$ Watt et al. ${ }^{15}$ and Wren et al. ${ }^{16}$ were used for presumptive identification.

Two horse blood-agar plates (Oxoid CM 331) were inoculated with sufficient of the test organism to produce semi-confluent growth. Disks containing penicillin $\mathrm{G} 2 \mathrm{u}$, kanamycin $1000 \mu \mathrm{g}$, vancomycin $5 \mu \mathrm{g}$ and colistin $10 \mu \mathrm{g}$, supplied on a ring (Mast Laboratories, M/ID8), were applied to one plate and single disks of metronidazole $2 \cdot 5 \mu \mathrm{g}$ and novobiocin $5 \mu \mathrm{g}$ were applied to the other. Zones of inhibition were measured after incubation anaerobically for 24 or $48 \mathrm{~h}$. The zones around the Mast ring were interpreted according to the manufacturer's instructions, based on the recommendations of Sutter and Finegold. ${ }^{14}$ Zones $>26 \mathrm{~mm}$ in diameter were interpreted as indicating sensitivity to metronidazole and of $>10 \mathrm{~mm}$ diameter as indicating sensitivity to novobiocin. ${ }^{16,17}$

\section{Biochemical tests}

These were based on methods recommended by Holdeman, Cato and Moore. ${ }^{18}$

Carbohydrate fermentation. Tests for fermentation (acid production) were performed in 3-ml volumes of Fastidious Anaerobe Broth (FAB, Lab M: code 71) containing $1 \%$ of glucose, fructose or mannose (added as a filter-sterilised $10 \%$ solution to the cooled, autoclaved medium). A heavy suspension of a 24- or 48-h culture of the test organism harvested from a blood-agar purity plate was made in $3 \mathrm{ml}$ of FAB without added carbohydrate, and three drops of this suspension were used to inoculate each test carbohydrate. The cultures were incubated anaerobically for at least $48 \mathrm{~h}$ or until no obvious increase in growth (assessed as turbidity) had occurred for $24 \mathrm{~h}$. The pH of each culture was measured with a Corning-Eel pH meter Model No. 7 and the change in $\mathrm{pH}$ was compared with that of an inoculated, incubated culture in FAB without added carbohydrate. All the strains tested produced a heavy turbid suspension in this broth after incubation for a maximum of 3 days.

The API 20A identification kit (Analytab Products Inc.) was used to examine any isolate that fermented any of the three carbohydrates tested by the conventional method.

Indole production and nitrate reduction. The tests were performed by the methods of Cowan ${ }^{19}$ in $3-\mathrm{ml}$ volumes of Indole-Nitrate Medium (BBL 11299) inoculated with the test organism and incubated anaerobically at $37^{\circ} \mathrm{C}$ for at least $48 \mathrm{~h}$.

\section{Gas chromatography}

Analysis of volatile fatty acid end-products of glucose metabolism was performed on 2-4-day cultures of each organism in FAB medium with glucose $1 \% \mathrm{w} / \mathrm{v}$ by the method of Gargan and Phillips. ${ }^{20} \mathrm{~A}$ Pye Unicam GCD chromatograph equipped with a flame ionisation detector was used to analyse the samples. A $10-\mu 1$ volume of the culture supernate was injected into a $1.5 \mathrm{~m} \times 0.4 \mathrm{~mm}$ glass column (Pye Unicam 9435-179-18051), packed with Chromosorb 101 (Applied Science Labs. Inc. 04825). Results were recorded on a Philips 8251 flat-bed recorder. The following settings were used for the detection of volatile and non-volatile fatty acids: column temperature $200^{\circ} \mathrm{C}$, injector and detector temperature $240^{\circ} \mathrm{C}$ and $\mathrm{O}_{2}$-free $\mathrm{N}_{2}$ carrier-gas flow rate $40 \mathrm{ml} / \mathrm{min}$. With this method the lower limits of detection were $0.1 \mathrm{mmol} / \mathrm{ml}$ except for lactic acid $(0.4 \mathrm{mmol} / \mathrm{ml})$ and succinic acid $(4 \mathrm{mmol} / \mathrm{ml})$.

\section{Whole-cell protein electrophoresis}

A loopful of growth from a 24- or 48-h culture on blood agar was suspended in two $50-\mathrm{ml}$ volumes of freshly prepared pre-reduced broth containing yeast extract $10 \%$, sodium thioglycollate $0.5 \%$, sodium 
chloride $2.5 \%$, sodium bicarbonate $0.4 \%$, glucose $1.0 \%$ and Tween $800.01 \%$ in Proteose Peptone No. 3 (Difco 0122-01-2). The cultures were incubated anaerobically for 24 or $48 \mathrm{~h}$ to obtain a heavy suspension of organisms. Purity was checked by subculture of one loopful of each 48-h broth culture on a non-selective horse-blood-agar medium, which was then incubated anaerobically for 5 days and examined carefully for the presence of contaminants. After centrifugation at approximately $3000 \mathrm{rpm}$, the deposit was washed twice in distilled water, and resuspended in $1 \mathrm{ml}$ of lysozyme (Sigma L-6876) $0.1 \%$ in $\mathrm{pH} 6.0$ buffer and incubated at $37^{\circ} \mathrm{C}$ for $3 \mathrm{~h}$. After lysis, $0 \cdot 1 \mathrm{ml}$ of sodium dodecyl sulphate (SDS) $20 \%$ was added to each preparation and the mixture was placed in a boiling water bath for $2 \mathrm{~min}$. The suspension was then centrifuged at $12000 \mathrm{rpm}$ for $30 \mathrm{~min}$ in an Anderman 5414 centrifuge and $1.0 \mathrm{ml}$ of the supernate was added to $0.2 \mathrm{ml}$ of sample buffer containing $0 \cdot 1625 \mathrm{M}$ Tris$\mathrm{HCl}, \mathrm{pH} 6.8$, SDS $2 \%$, glycerol $10 \%$ and 2-mercaptoethanol $5 \%$.

Proteins were separated by SDS-polyacrylamide gel electrophoresis (PAGE) in 10\% gels as described by Jackman. ${ }^{10}$ The separation gel was prepared by adding a mixture of $67 \mathrm{ml}$ of monomer (acrylamide $30 \%$, bis acrylamide $2.7 \%$ ), $50 \mathrm{ml}$ of separation buffer (1.5 M Tris- $\mathrm{HCl}, \mathrm{pH} \mathrm{8.8)}$ and distilled water (to $193 \mathrm{ml}$ ) to $2 \mathrm{ml}$ of SDS $10 \%$, ammonium persulphate $90 \mathrm{mg}$ in $5 \mathrm{ml}$ of distilled water and TEMED $60 \mu \mathrm{l}$. The total volume was thus $200 \mathrm{ml}$. The stacking gel contained the same ingredients in different amounts: $10 \mathrm{ml}$ of monomer, $15 \mathrm{ml}$ of buffer and distilled water to $54 \mathrm{ml}$; $0.6 \mathrm{ml}$ of SDS $10 \%$, ammonium persulphate $60 \mathrm{mg}$ in $5 \mathrm{ml}$ of distilled water and TEMED $40 \mu \mathrm{l}$. The tank buffer consisted of $0 \cdot 25 \mathrm{M}$ Tris, $\mathrm{pH} 8 \cdot 3,0 \cdot 192 \mathrm{M}$ glycine and SDS $0 \cdot 1 \%$.

Samples of $100 \mu \mathrm{l}$ were placed in the wells, along with bromophenol blue in some samples, and a constant current of $30 \mathrm{~mA}$ was applied in a Bio Rad 165-1572 Multi-6 gel protean cell with a Pharmacia EPS 500/400 solid power supply, until the tracker dye had travelled $100 \mathrm{~mm}$ from the stacking gel-separation gel interface. The gels were then removed and stained in Coomassie Blue $0.125 \%$ overnight and destained in acetic acid $10 \%$ plus methanol $25 \%$ in distilled water until the background was clear. Gels were then dried in a slab gel drier (LKB 2003).

A Vitatron TLD 100 scanning densitometer (MSE Instruments) was used to scan each gel. The following settings were used: tungsten lamp, red filter 603, slit width $0.25 \mathrm{~mm}$, slit length $3 \mathrm{~mm}$, scanning speed $1 \mathrm{~mm} / \mathrm{s}$. The densitometer was attached to a Commodore PET 3032 microcomputer and 3040 disk unit via an Ortholog 181 analogue-digital converter (Ortholog Ltd). The computer programs used for analysis were as described by Jackman et al. ${ }^{21}$ The first program accepted from the converter 10 voltage values per $\mathrm{mm}$ of gel scanned. The second program searched the first 50 points of each scan, and accepted the highest value as the beginning of the gel, and ignoring the next mm so as to exclude the gel start peak, averaged the subsequent 1000 points in groups of 10 , so that each electrophoretic pattern was represented by 100 values. The third program compared the traces, searched for best fit, and formed a similarity matrix based on the correlation coefficient of Sneath and Sokal. ${ }^{22}$ The fourth program applied the unweighted pair group method using averages (UPGMA) of Sneath and Sokal $^{22}$ to cluster the similarity matrix generated by the third program, and the dendrogram was then plotted.

The gels were also examined visually for evidence of major differences or similarities within and between conventionally identified species and computer-derived groups. The findings were confirmed by independent observation by the three authors.

\section{Results}

\section{Conventional tests}

All named reference strains produced expected results in conventional tests (table I). However, it was noted that the type strain of $P$. micros was resistant to novobiocin, although Wren et al. ${ }^{16}$ had previously reported that this species was sensitive on the basis of tests on two clinical isolates. This observation was taken into account in identification of clinical isolates and the Hare Group organisms.

The reactions of the Hare Group organisms in conventional tests are also shown in table I. Only two of the 10 organisms examined could be identified to species level, Hare group IV (NCTC nos. 9804 and 9815) as $P$. magnus. Strains NCTC 9811 and 9821 were asaccharolytic and could not be allocated to species. The six remaining strains were saccharolytic and produced large amounts of butyric acid from glucose metabolism. Although some strains fermented several carbohydrates they could not be identified by the schemes outlined by Holdeman Moore et al. ${ }^{2}$ or by Hardie. $^{3}$

The provisional identification of the 87 clinical isolates and their reactions in conventional biochemical tests are shown in table II. All these organisms were asaccharolytic. A characteristic volatile fatty acid profile was used to identify 19 strains as $P$. anaerobius. Fifteen indole-positive butyrate-producing strains were identified as $P$. asaccharolyticus and the indole-negative butyrate-positive strains were identified as $\boldsymbol{P}$. prevotii. Thirty-four butyrate-non-producing strains were speciated purely by cell size and colonial appearance. Thirty strains were identified as $P$. magnus because their cell size was $>0.6 \mathrm{~mm}$ and four were identified as $P$. micros because they were small and had a colonial appearance similar to that of the type strain of $P$. micros. The other three butyrate-nonproducing novobiocin-resistant isolates were not allocated to species. 
Table I. Reference strains of anaerobic cocci and their important biochemical reactions

\begin{tabular}{|c|c|c|c|c|c|c|c|}
\hline & & \multicolumn{5}{|c|}{ Results in tests for } \\
\hline Reference strains and numbers as received & & & coagulase & $\begin{array}{c}\text { glucose } \\
\text { fermentation }\end{array}$ & $\begin{array}{l}\text { indole } \\
\text { production }\end{array}$ & $\begin{array}{l}\text { nitrate } \\
\text { reduction }\end{array}$ & $\begin{array}{l}\text { volatile fatty acid } \\
\text { production }\end{array}$ \\
\hline \multicolumn{8}{|c|}{ Hare Group organisms* } \\
\hline NCTC & 9801 & Hare Group I & - & + & + & - & $\mathrm{A}, \mathrm{p}, \mathrm{B}$ \\
\hline NCTC & 9803 & Hare Group III & - & + & + & - & $\mathrm{A}, \mathrm{p}, \mathrm{B}$ \\
\hline NCTC & 9814 & Hare Group III & - & + & + & - & $\mathrm{A}, \mathrm{p}, \mathrm{B}$ \\
\hline NCTC & 9804 & Hare Group IV & - & - & - & - & A \\
\hline NCTC & 9815 & Hare Group IV & - & - & - & - & A \\
\hline NCTC & 9808 & Hare Group VIIa & - & + & - & - & A, p, B \\
\hline NCTC & 9810 & Hare Group VIII & - & + & - & - & $\mathrm{A}, \mathrm{p}, \mathrm{B}$ \\
\hline NCTC & 9820 & Hare Group VIII & - & + & - & - & $\mathrm{A}, \mathrm{p}, \mathrm{B}$ \\
\hline NCTC & 9811 & Hare Group IX & - & - & - & - & A \\
\hline NCTC & 9821 & Hare Group IX & - & - & - & - & A \\
\hline \multicolumn{8}{|c|}{ Named and reference strains $\dagger$} \\
\hline ATCC & 27337 & P. anaerobius & - & $\mathbf{w}$ & - & - & $A, p, i b, b, I C, 1, s$ \\
\hline NCIB & 10074 & P. asaccharolyticus (ATCC 14963) $\ddagger$ & - & - & + & - & $\mathrm{A}, \mathrm{p}, \mathrm{B}, 1, \mathrm{~s}$ \\
\hline ATCC & 29427 & P. indolicus & + & - & + & + & $\mathrm{A}, \mathrm{p}, \mathrm{B}$ \\
\hline ATCC & 11088 & $P$. indolicus & + & - & + & + & $\mathrm{A}, \mathrm{p}, \mathrm{B}$ \\
\hline ATCC & 15794 & P. magnus & - & - & - & - & $\mathrm{A}, \mathrm{l}, \mathrm{s}$ \\
\hline V5464-1 & & P. micros (ATCC 33270) $\S$ & - & - & - & - . & $\mathrm{A}, 1, \mathrm{~s}$ \\
\hline NCIB & 10768 & P.prevotii (ATCC 14952) $\ddagger$ & - & - & - & - & $\mathrm{A}, \mathrm{p}, \mathrm{B}, \mathrm{l}, \mathrm{s}$ \\
\hline ATCC & 14953 & P. saccharolyticus & - & + & - & + & $A, 1$ \\
\hline ATCC & 27731 & Peptococcus niger & - & - & - & - & $\mathrm{A}, \mathrm{p}, \mathrm{ib}, \mathrm{B}, \mathrm{iv}, \mathrm{C}, \mathrm{l}, \mathrm{s}$ \\
\hline V0546 & & Str. parvulus (ATCC 33793)§ & - & + & - & - & $\mathrm{A}, \mathrm{l}, \mathrm{s}$ \\
\hline ATCC & 27340 & Str. productus & - & + & - & - & $\mathrm{A}, \mathrm{p}, 1, \mathrm{~s}$ \\
\hline
\end{tabular}

Numbers in parenthesis are ATCC numbers of strains received from other sources.

A, acetic; B, butyric, IB, isobutyric; C, caproic, IC, isocaproic; L, lactic; S, succinic; IV, isovaleric.

Upper case, large amounts; lower case, small amounts.

* Obtained from the National Collection of Type Cultures, Central Public Health Laboratory, 61 Colindale Avenue, London.

+ Obtained from the American Type Culture Collection, Rockville, Maryland 20852, USA, except where otherwise stated.

$\ddagger$ Obtained from the National Collection of Industrial Bacteria, Torry Research Station, Aberdeen.

$\S$ Obtained from Professor L. V. Holdeman, Blacksburg, VA, USA.

Table II. Biochemical reactions of clinical isolates of anaerobic cocci

\begin{tabular}{|c|c|c|c|c|c|c|}
\hline \multirow{2}{*}{$\begin{array}{l}\text { Provisional } \\
\text { identification }\end{array}$} & \multirow{2}{*}{$\begin{array}{c}\text { Number of } \\
\text { isolates }\end{array}$} & \multicolumn{4}{|c|}{ Biochemical reactions } & \multirow{2}{*}{$\begin{array}{c}\text { Volatile fatty acids } \\
\text { produced }\end{array}$} \\
\hline & & Co & G1 & In & $\mathrm{Ni}$ & \\
\hline P. anaerobius & 19 & - & - & - & - & $A, p, i b, i v, I C, 1, s$ \\
\hline P. asaccharolyticus & 15 & - & - & + & - & $\mathrm{A}, \mathrm{p}, \mathrm{B}, \mathrm{l}, \mathrm{s}$ \\
\hline P. magnus & 30 & - & - & - & - & $\mathrm{A}, \mathrm{p}, \mathrm{l}, \mathrm{s}$ \\
\hline P. micros & 4 & - & - & - & - & $\mathrm{A}, \mathrm{p}, \mathrm{l}, \mathrm{s}$ \\
\hline$P$. prevotii & 16 & - & - & - & - & $\mathrm{A}, \mathrm{p}, \mathrm{B}, \mathrm{l}, \mathrm{s}$ \\
\hline $\begin{array}{l}\text { Unidentified novobiocin resist- } \\
\text { ant strains* }\end{array}$ & 3 & - & - & - & - & $\mathrm{A}, \mathrm{p}, \mathrm{l}, \mathrm{s}$ \\
\hline
\end{tabular}

$\mathrm{Co}$, coagulase; GI, glucose fermentation; In, indole production; $\mathrm{Ni}$, nitrate reduction.

Volatile fatty acids: see table I.

* Not clearly morphologically P. micros.

\section{Protein electrophoresis : computerised analysis}

Fig. 1 shows a dendrogram based on the numerical analysis of protein patterns of 108 strains of anaerobic cocci, including 87 clinical isolates and 21 reference strains (including four type strains) by the correlation coefficient and UPGMA clustering.

No single similarity level divided the strains into completely satisfactory groups but four broad groups (A-D) were defined at a similarity of $0 \cdot 30$, and several distinct clusters were found within each group. These will be described in detail.

Group $A$. This group contained 41 organisms and was dominated by strains identified conventionally as $P$. anaerobius and $P$. asaccharolyticus. Eighteen of the 19 strains of $P$. anaerobius examined, including the type strain ATCC 27337, and 12 of the 15 strains of $P$. asaccharolyticus examined, including the type strain ATCC 14963 (NCIB 10074), fell into this group. Four strains conventionally identified as $P$. prevotii, two 


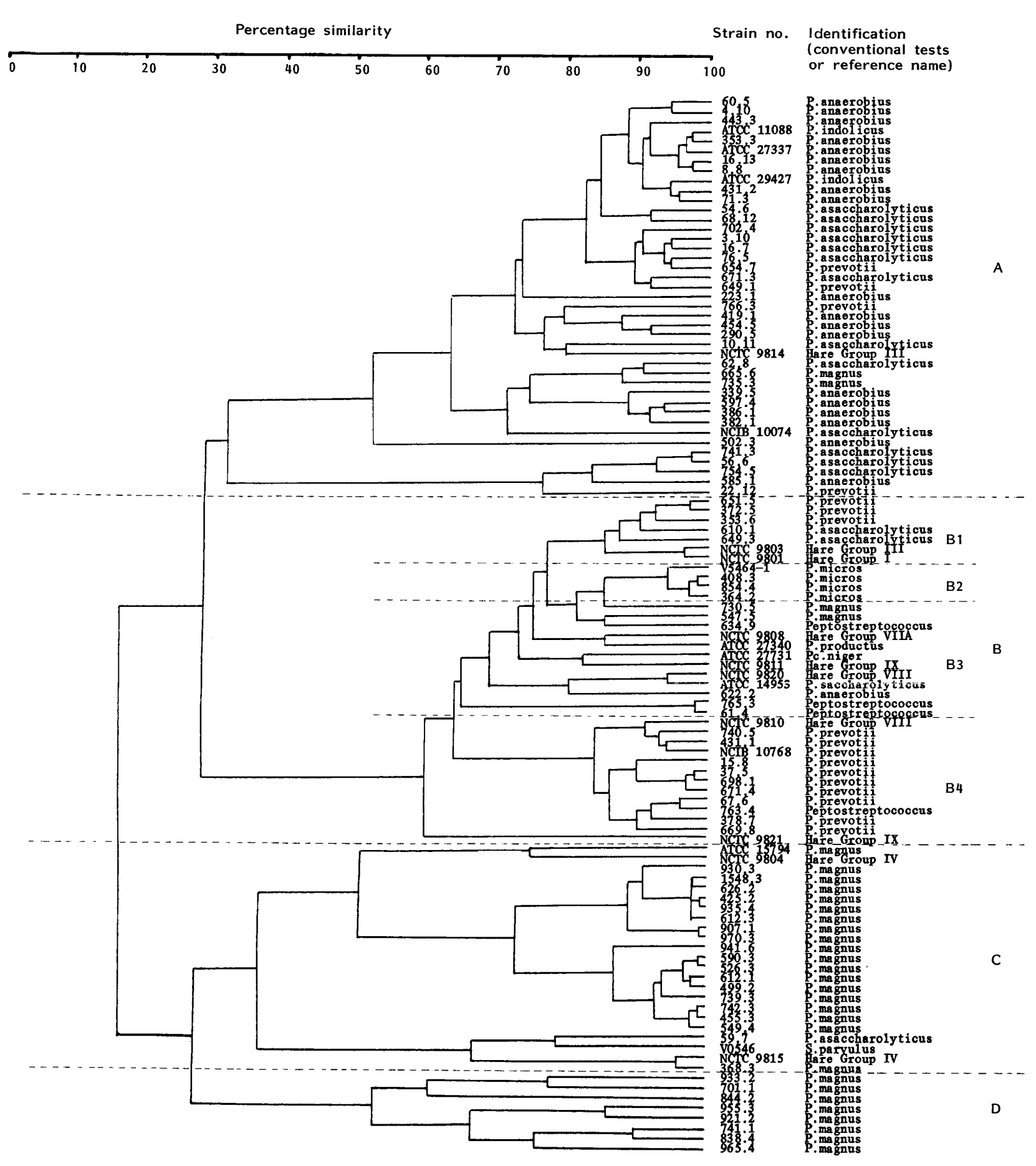

Fig. 1. Dendrogram based on electrophoretic protein patterns. The similarity coefficient was the correlation coefficient (r) and UPGMA clustering was used. The best fit between patterns was found by calculation of $\mathrm{r}$ at lateral shifts of up to $2 \mathrm{~mm}$ between patterns.

strains identified as $P$. magnus, and three other reference strains $-P$. indolicus ATCC nos. 11088 and 29427 and Hare Group III NCTC 9814-were also found in Group A.

Group $B$. This group contained 36 strains and was very complex, but discrete clusters were found that merit particular attention.

Cluster B1 contained three strains identified as $P$. prevotii, two strains identified as $P$. asaccharolyticus, Hare Group III strain NCTC 9803 and Hare Group I strain NCTC 9801. These organisms reacted similarly in conventional tests. All produced butyrate as a major fatty-acid end-product of glucose metabolism. $P$. prevotii and $P$. asaccharolyticus were distinguished on the basis of indole production only, and both $\boldsymbol{P}$. asaccharolyticus and the two Hare Group organisms were indole positive. However, the Hare Group organisms fermented various carbohydrates and gave different reactions in the tests for hydrolysis of substrates by pre-formed enzymes.

Cluster B2 contained the three clinical isolates and the type strain of $P$. micros (V5464). The electrophoretic protein patterns of these strains had an average correlation of 0.90 . 
Two clinical isolates in cluster B3 were identical (765.3 and 61.4), but differed from all other strains. The rest of the organisms in this cluster were mostly known to belong to quite different species.

Cluster B4 contained nine clinical strains identified as $\boldsymbol{P}$. prevotii, reference strains $\boldsymbol{P}$. prevotii ATCC 14952 (NCIB 10768) and Hare Group VIII (NCTC 9810), and one clinical isolate identified only as a Peptostreptococcus species. Strain NCTC 9810 was biochemically similar to $P$. prevotii as it was indole negative and produced butyrate from glucose metabolism, but it fermented several carbohydrates, whereas $P$. prevotii is asaccharolytic.

Group $C$. This group contained 23 organisms including three reference strains identified as $\boldsymbol{P}$. magnus - the type strain of the species, ATCC 15794, and two Hare Group IV organisms (NCTC nos 9804 and 9815) - and 18 of the 30 clinical isolates identified as $P$. magnus. One clinical isolate identified as $P$. asaccharolyticus (59.7) and the type strain of Streptococcus parvulus were also placed in Group C.

Group $D$. This group contained only clinical isolates identified as $P$. magnus.

\section{Protein electrophoresis : visual assessment}

The results of the assessment of a combination of the results of conventional tests, computer-derived Groups, and visual examination of gels (fig. 2) are shown in table III.

The 19 clinical strains identified by conventional means as $P$. anaerobius, including one clinical isolate $(622 \cdot 2)$ that was placed by computer analysis in Group B despite the clear similarity of its gel to those of strains in Group A, and the type strain ATCC 27337, all had a similar protein pattern characterised by a single dominant high mol.-wt band. They formed a single combined Group Aa.

Of the 15 isolates identified conventionally as $P$. asaccharolyticus, 12 had patterns similar to that of the type strain NCIB 10074 (ATCC 14963), characterised by a pair of high mol.-wt bands. These, with four strains conventionally identified as $P$. prevotii on the basis of a negative indole reaction, two reference strains of $P$. indolicus and a saccharolytic Hare Group III strain (NCTC 9814) clustered into computed Group $A$ and all were separated visually from $P$. anaerobius strains into combined Group $\mathrm{Ab}$. The remainder of computed Group A was made up of two clinical isolates conventionally identified as $P$. magnus that resembled each other but were distinct from any of the type or reference strains.

Two clinical strains identified as $P$. asaccharolyticus, two reference strains of saccharolytic Hare Groups I

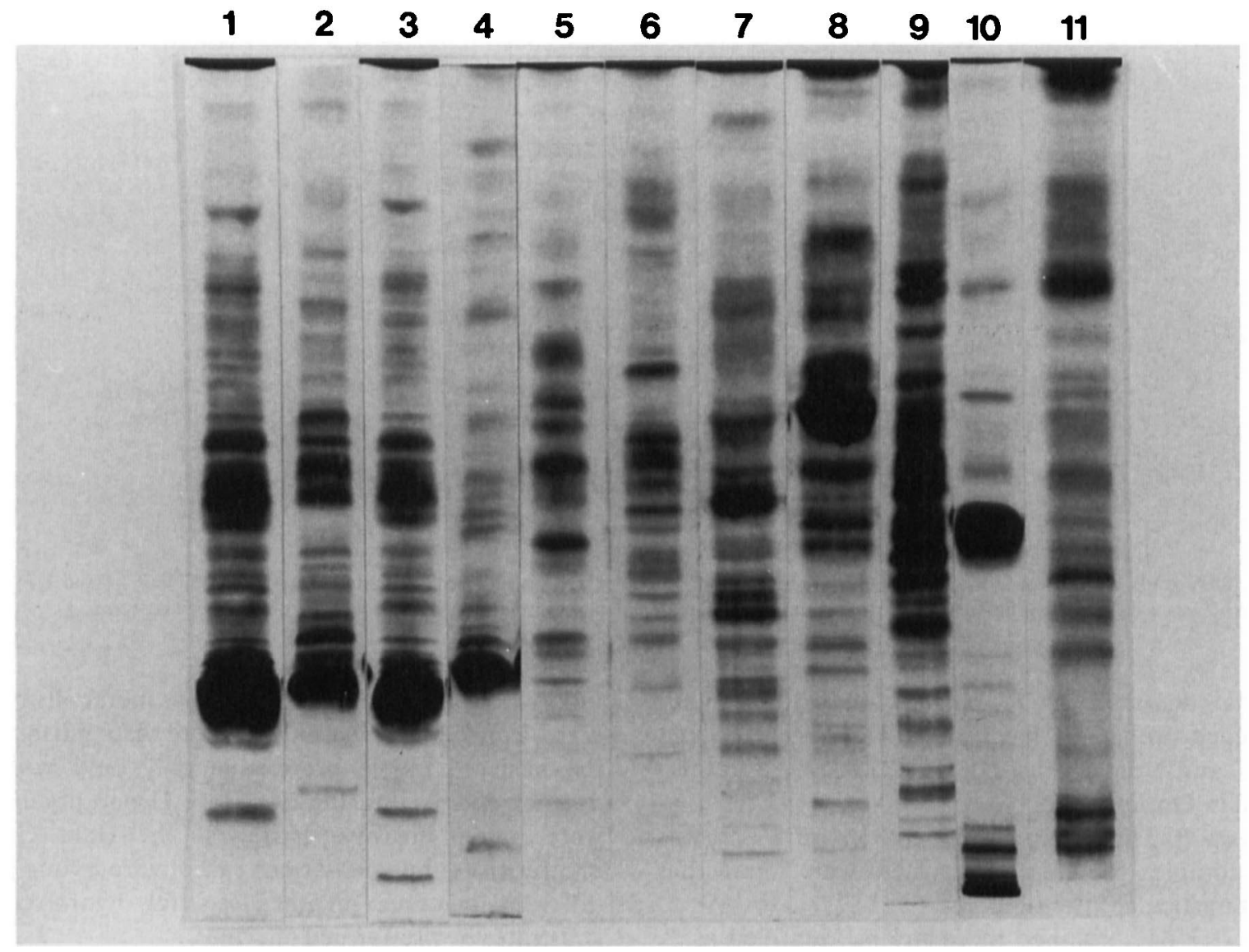

Fig. 2. Protein electrophoretic patterns of: 1, P. anaerobius ATCC 27337 (type strain); 2, P. asaccharolyticus-posšibly homology group 1, NCIB 10074, ATCC 14953 (type strain); 3, $P$. indolicus ATCC 11088; 4, possible new taxon 1 (clinical isolate); 5, $P$. asaccharolyticus possibly homology group $2 ; 6, P$. micros V5464-1, ATCC 33270 (type strain); 7, possible new taxon 2 (clinical isolate); 8, possible $P$. prevotii NCIB 10768, ATCC 14952 (reference strain); 9, P. magnus ATCC 15794 (type strain), 10, $P$. magnus-like (clinical isolate); 11 , possible $P$. variabilis (clinical isolate). 
Table III. Allocation of strains to groups on the basis of conventional biochemical tests, and numerical analysis combined with visual inspection of protein electrophoretic patterns

\begin{tabular}{|c|c|c|c|c|c|}
\hline \multirow{2}{*}{ Species } & \multirow{2}{*}{$\begin{array}{l}\text { Type } \\
\text { strain }\end{array}$} & \multirow{2}{*}{$\begin{array}{l}\text { Reference } \\
\text { strains }\end{array}$} & \multirow{2}{*}{$\begin{array}{l}\text { Conventional identification } \\
\text { of clinical isolates } \\
\text { (number) }\end{array}$} & \multicolumn{2}{|c|}{ Protein electrophoresis } \\
\hline & & & & $\begin{array}{l}\text { computed } \\
\text { groups }\end{array}$ & $\begin{array}{l}\text { combined } \\
\text { groups }\end{array}$ \\
\hline P. anaerobius & $\begin{array}{l}\text { ATCC } \\
27337\end{array}$ & & $\begin{array}{l}\text { P. anaerobius (18) } \\
\text { P. anaerobius (1) }\end{array}$ & $\begin{array}{l}\text { A } \\
\text { B }\end{array}$ & $\begin{array}{l}\mathrm{Aa} \\
\mathrm{Aa}\end{array}$ \\
\hline $\begin{array}{l}\text { P. asaccharolyticus } \\
\text { homology group } 1\end{array}$ & $\begin{array}{l}\text { NCIB } \\
10074\end{array}$ & $\begin{array}{l}\text { Hare III NCTC } 9814 \\
P . \text { indolicus } \\
\text { ATCC } 11088 \\
\text { ATCC } 29427\end{array}$ & $\begin{array}{l}\text { P. asaccharolyticus (12) } \\
\text { P. prevotii (4) }\end{array}$ & $\begin{array}{l}\text { A } \\
\text { A }\end{array}$ & $\begin{array}{l}\mathrm{Ab} \\
\mathrm{Ab}\end{array}$ \\
\hline Possible new taxon 1 & $\cdots$ & $\ldots$ & P. magnus (2) & A & Ac \\
\hline \multirow[t]{2}{*}{$\begin{array}{l}\text { P. asaccharolyticus } \\
\text { possibly homology } \\
\text { group } 2\end{array}$} & $\ldots$ & Hare I NCTC $9801^{\mathrm{s}}$ & $\begin{array}{l}\text { P. asaccharolyticus (2) } \\
\text { P. prevotii (3) }\end{array}$ & $\begin{array}{l}\text { B1 } \\
\text { B1 }\end{array}$ & $\begin{array}{l}\mathrm{Ba} \\
\mathrm{Ba}\end{array}$ \\
\hline & & Hare III NCTC $9803^{\mathrm{s}}$ & & B1 & $\mathrm{Ba}$ \\
\hline P. micros & V5464-1 & $\begin{array}{l}\text { (Hare IX NCTC 9821) } \\
\text { (Hare IX NCTC 9811) }\end{array}$ & P. micros (3) & B2 & $\mathbf{B b}$ \\
\hline $\begin{array}{l}\text { Possible new taxon } 2 \\
\text { Possible P.prevotii }\end{array}$ & $\begin{array}{l}\cdots \\
\cdots\end{array}$ & $\begin{array}{l}\ldots \\
\text { NCIB } 10768 \\
\text { Hare VIII NCTC } 9810^{s} \\
\text { Hare VIII NCTC } 9820^{s} \\
\text { Hare VIIa NCTC } 9808^{s}\end{array}$ & $\begin{array}{l}\text { Peptostreptococcus spp (2) } \\
\text { P.prevotii (9) }\end{array}$ & $\begin{array}{l}\text { B3 } \\
\text { B } \\
\text { B } \\
\text { B } \\
\text { B }\end{array}$ & $\begin{array}{l}\text { Bc } \\
\text { Bd } \\
\text { Bd } \\
\text { Bd } \\
\text { Bd }\end{array}$ \\
\hline P. magnus & $\begin{array}{l}\text { ATCC } \\
15794\end{array}$ & Hare IV NCTC 9804 & (0) & $\mathrm{C}$ & $\mathrm{Ca}$ \\
\hline P. magnus-like & $\ldots$ & Hare IV NCTC 9815 & P. magnus (18) & $\mathrm{C}$ & $\mathrm{Cb}$ \\
\hline Possible $P$. variabilis & $\ldots$ & $\cdots$ & P. magnus (8) & D & $\mathrm{Da}$ \\
\hline Unallocated* & & & (8) & & \\
\hline
\end{tabular}

s, Saccharolytic strains.

* Unallocated strains were: clinical isolates $P$. magnus $(2 ; 730 \cdot 5,547 \cdot 5)$, Peptostreptococcus sp. (1; 634.9), P. asaccharolyticus (1; 59.7) (conventional identification); Pc. niger, ATCC 27731; Str. productus, ATCC 27340; Str. parvulus, V0546; $P$. saccharolyticus, ATCC 14953.

(NCTC 9801) and III (NCTC 9803) and three strains originally identified as $P$. prevotii made up combined Group Ba.

Three clinical isolates of $P$. micros and the type strain V5464 (ATCC 33270) came in computed Group B as a single cluster B2. A Hare Group IX organism (NCTC 9821), falling into computed Group B4, appeared similar visually, and the five organisms were therefore allocated to combined Group Bb. On the basis of visual inspection, the Hare Group IX organism NCTC 9811 could also belong to combined Group Bb.

Two unidentified clinical isolates (new taxon 2) formed a separate group both by computation and visually (combined Group Bc).

Of the 16 isolates provisionally identified as $P$. prevotii, nine of the 12 not clustering with $P$. asaccharolyticus had patterns resembling a reference strain (ATCC 14952, NCIB 10768). Unfortunately the type strain of $P$. prevotii was lost during the study. One Hare Group VIII strain (NCTC 9810) fell into the same cluster (Bd) and two more were added on the basis of visual inspection (Hare Group VIII, NCTC 9820; Hare Group VIIa NCTC 9808). The Hare Group IX strain NCTC 9821, although in this computed Group, was visually in Group Bb (see above).
In computed Group C, only the type strain of $P$. magnus and a Hare Group IV strain (NCTC 9804) had the same protein pattern on visual inspection (Ca). Eighteen other $P$. magnus strains and a Hare Group IV strain (NCTC 9815) clustered into a separate but contiguous group, and visually were very similar to each other $(\mathrm{Cb})$.

Group D was made up entirely of clinical isolates identified as $P$. magnus $(\mathrm{Da})$, and all were similar visually.

Eight strains, including four reference strains not expected to find a place, were not allocated by the combination of computerised and visual analysis. Three of the reference strains (Pc. niger ATCC 27731, $P$. productus ATCC 27340 and $P$. saccharolyticus ATCC 14953) and three clinical isolates (730.5, 547.5 and 634.9) fell into computed Group B3, and the other two organisms (Str. parvulus V546 and clinical isolate 59.7) were allocated to computed Group C.

\section{Discussion}

The groups created by the numerical analysis alone were governed, to a certain extent, by various confounding factors, some of which proved impossible 
to overcome. Some groups of strains possessed large amounts of one or two proteins with the same mol. wt, and this character was over-weighted by the correlation coefficient used. This was the major problem with the species $P$. anaerobius and $P$. asaccharolyticus, and resulted in the grouping together of the members of these two species. Furthermore, the limitations of the similarity coefficient used and difficulties with the reproducibility of the electrophoresis affected the numerical analysis. We therefore concluded that a numerical analysis qualified by visual assessment, provided the most acceptable taxonomic groups.

This combination of visual comparison and numerical analysis of whole-cell protein patterns resulted in a more satisfactory taxonomic structure which, when comparison was possible, largely endorsed the findings of the few other large chemotaxonomic studies on the Peptococcaceae, ${ }^{4-6}$ and of the only other studies of proteins of selected anaerobic cocci that we have been able to find. ${ }^{11,23}$

\section{$P$. anaerobius}

We found, in agreement with Ezaki et al., ${ }^{4}$ Huss et $a l .{ }^{5}$ and Smith et al.,$^{23}$ that the species $P$. anaerobius is homogeneous and distinct from the other asaccharolytic, anaerobic gram-positive cocci. This species can be easily and accurately identified by its characteristic volatile fatty-acid pattern as well as by protein electrophoresis. Like Smith et al., ${ }^{23}$ who examined only surface proteins, we found that most isolates had a single major intense protein band. Most of our isolates came from the vagina or miscellaneous skin and soft tissue infections.

\section{The butyrate-producing cocci}

We concluded that differentiation of $P$. prevotii and $P$. asaccharolyticus on the basis only of indole production is unreliable. The species $P$. asaccharolyticus, as currently defined, is heterogeneous. We distinguished two groups which appear to correspond to two of the three homology groups distinguished by Ezaki et al., ${ }^{4}$ each containing clinical isolates identified conventionally as $P$. asaccharolyticus or $P$. prevotii.

We agree with Huss et al. ${ }^{5}$ and with Murdoch et al. ${ }^{7}$ that $\boldsymbol{P}$. indolicus is closely related to $\boldsymbol{P}$. asaccharolyticus - indeed we were unable to differentiate the protein patterns of two reference strains of $P$. indolicus from those of the type strain of $P$. asaccharolyticus ATCC 14953. The strains of Hare Groups I and III were allocated to the second homology group-both Weiss ${ }^{6}$ and Huss et al. ${ }^{5}$ relate them to $P$. asaccharolyticus. Most of our isolates in putative homology Group 1 came from the female genital tract, while those from putative homology Group 2 came from more varied sites.

The species $P$. prevotii appears to be homogeneous on the basis of protein electrophoresis, but we were not able to include the type strain (ATCC 9321) in our final analysis although we did include a reference strain (ATCC 14952). However, this strain may not be typical of $P$. prevotii as it is now described by Holdeman Moore et al. ${ }^{2}$ On the basis of visual inspection we also allocated three saccharolytic Hare Group organisms (VIIa, NCTC 9808; VIII, NCTC nos. 9810 and 9820) to this group. Both Weiss ${ }^{6}$ and Huss $e t$ al. ${ }^{5}$ related Hare Group VIII to $P$. prevotii. Our isolates of " $P$. prevotii" came from various sites, including the vagina. Smith et al. ${ }^{23}$ found that their $P$. prevotii was heterogeneous but, as we did originally, could have included indole-negative $P$. asaccharolyticus strains.

\section{P. micros}

We concluded that the species $P$. micros is homogeneous and, in agreement with Huss et al., ${ }^{5}$ that Hare Group IX organisms probably belong to this species. $P$. micros has been previously reported to be sensitive to novobiocin, ${ }^{16}$ but in our experience, the type strain, all clinical isolates and both Hare Group IX organisms were resistant. It has now been suggested that $P$. micros can be differentiated from $P$. magnus by its strong alkaline phosphatase activity ${ }^{18}$ and by the production of a wider range of aminopeptidases. ${ }^{7}$ Our three clinical strains came from pelvic pus, a liver abscess and a paronychia.

\section{P. magnus}

We concluded, as did Smith et al., ${ }^{23}$ that, on the basis of protein patterns, $P$. magnus, as currently defined, is heterogeneous. In agreement with Weiss ${ }^{6}$ and Huss et al., ${ }^{5}$ we found that the Hare Group IV organisms are $P$. magnus. Cato et al. ${ }^{11}$ reported that the protein patterns of the type strains of $P$. magnus and $P$. variabilis were quite distinct, although the species $P$. variabilis was no longer recognised and had become a synonym of $P$. magnus. In our study, the protein patterns of the strains identified as $P$. magnus fell into two distinct groups and the second of the groups, Da, was characterised by a protein pattern that greatly resembled that published by Cato for the species $P$. variabilis. Unfortunately, the type strain of the previously recognised species $P$. variabilis was not included in our study, and we were unable to find any conventional test that could be used to distinguish between the two "species". Most of the isolates in the $P$. magnus-related groups came from skin infections (axilla, paronychia, breast, sebaceous cyst etc.) and only one came from the vagina.

\section{The Hare Groups}

The Hare Groups of anaerobic cocci ${ }^{12}$ deposited with the NCTC continue to be a puzzle even when the facultatively anaerobic organisms have been excluded. Protein electrophoresis contributed to the elucidation of some of the problems. We agree with others that 
Groups I and III are related to P. asaccharolyticus ${ }^{6}$ but cannot agree with Huss et al. ${ }^{5}$ that they resemble $P$. prevotii once indole-negative $P$. asaccharolyticus strains have been removed from that species, or with Hare ${ }^{12}$ himself that Group I is $S$. putridus and that Group III is Staphylococcus aureus.

We believe that Hare Group III (NCTC 9814) is closely related to the $P$. asaccharolyticus homology group 1 of Ezaki et al. ${ }^{4}$ but since it is saccharolytic we cannot allocate it definitely to that group. The second Hare Group III organism (NCTC 9803) and Hare Group I (NCTC 9801), both saccharolytic strains, are closely related accordingly to Weiss ${ }^{6}$ and belong to a second group of $P$. asaccharolyticus which we believe may be homology group 2 of Ezaki et al. $^{4}$

One Hare Group IV strain (NCTC 9804) was clearly $P$. magnus, but the other belonged to a $P$. magnus-like group which otherwise contained only clinical isolates. This result is compatible with those of Weiss ${ }^{6}$ and Huss et al. ${ }^{5}$ and of Hare ${ }^{12}$ himself who believed that the two organisms were of different species.

Although the protein patterns of Hare Groups VIIa and VIII appeared similar to the eye, only Group VIII, NCTC 9810 could be related convincingly to the group that we called $P$. prevotii, in agreement with Huss et al. ${ }^{5}$ Again, the strains were saccharolytic and the true grouping could be more in relation to $P$. tetradius (Gaffkya anaerobia) of Ezaki et al. ${ }^{4}$ but we made no direct comparisons.

Both Hare Group IX organisms, which are asaccharolytic, were related to $P$. micros although the protein patterns were not identical. In this we agree with Weiss ${ }^{6}$ and Huss et al., ${ }^{5}$ but not with $\mathrm{Hare}^{12}$ who

\section{References}

1. Rogosa M. Peptococcaceae. In: Buchanan RE, Gibbons NE (eds) Bergey's Manual of determinative bacteriology, 8th edn. Baltimore, Williams and Wilkins Co. 1974: 517-525.

2. Holdeman Moore LV, Johnson JL, Moore WEC. Genus Peptostreptococcus. In: Sneath PHA, Mair NS, Sharpe ME, Holt JG (eds) Bergey's Manual of systematic bacteriology, vol 2. Baltimore, Williams and Wilkins. 1986: 1083-1092.

3. Hardie JM. Anaerobic streptococci. In: Sneath PHA, Mair NS, Sharpe ME, Holt JG (eds) Bergey's Manual of systematic bacteriology, vol 2. Baltimore, Williams and Wilkins. 1986: 1066-1068.

4. Ezaki T, Yamamoto N, Ninomiya K, Suzuki S, Yabuuchi E. Transfer of Peptococcus indolicus, Peptococcus asaccharolyticus, Peptococcus prevotii, and Peptococcus magnus to the genus Peptostreptococcus and proposal of Peptostreptococcus tetradius sp. nov. Int J Syst Bacteriol 1983; 33: 683-698.

5. Huss VAR, Festl H, Schleifer KH. Nucleic acid hybridization studies and deoxyribonucleic acid base compositions of anaerobic, gram-positive cocci. Int J Syst Bacteriol 1984; 34: 95-101.

6. Weiss N. Cell wall structure of anaerobic cocci. Revue de l'Institut Pasteur de Lyon 1981 ; 14 : 53-59.

7. Murdoch DA, Mitchelmore IJ, Tabaqchali S. Identification of gram-positive anaerobic cocci by use of systems for detecting pre-formed enzymes. J Med Microbiol 1988; 25 : 289-293.

8. Schreckenberger PC, Celig DM, Janda WM. Clinical evaluation of the Vitek ANI Card for identification of anaerobic bacteria. J Clin Microbiol 1988; 26: 225-230. thought that they could be Staph. anaerobius, a synonym of $P$. magnus.

In addition to the recognised species we found evidence for two new taxonomic groups, each made up of two clinical isolates. The organisms in one group were identified conventionally as $P$. magnus, but differed greatly in protein patterns. The two clinical isolates in the other new group were identified conventionally only as Peptostreptococcus sp. and were allocated by the computer to Group B3.

One area of the dendrogram, the greater part of computed Group B3 was completely unsatisfactory. It contained the unrelated organisms $P c$. niger, $P$. (now Str.) productus, $P$. (now Staph.) saccharolyticus, one Hare Group IX strain (NCTC 9811) and three clinical isolates, none of which had protein patterns like any of the reference strains. These organisms require further study.

Whole-cell protein electrophoresis is a relatively easy-to-perform investigation that examines a large proportion of the products of the bacterial genome. However, practical problems affect the reproducibility of the technique and make numerical analysis of the protein patterns difficult. Furthermore, anaerobic gram-positive cocci are difficult organisms to work with, and problems encountered in this study with the standardisation and reproducibility of sample preparation exacerbated the difficulties of numerical analysis. Despite these problems, visual comparison of the protein patterns showed that the differences between many of the strains tested was large, and if the practical problems can be overcome, numerical analysis of whole-cell protein patterns has great potential.

9. Jackman PJH. Bacterial taxonomy based on electrophoretic whole-cell protein patterns. In: Goodfellow M, Minnikin EE (eds) Chemical methods in bacterial systematics. The Society for Applied Bacteriology Technical Series no. 20. London, Academic Press. 1985: 115-129.

10. Jackman PJH. Microbial systematics based on electrophoretic whole-cell protein patterns. In: Colwell RR, Grigorova R (eds) Methods in microbiology, vol 19. London, Academic Press. 1987: 209-225.

11. Cato EP, Johnson JL, Hash DE, Holdeman LV. Synonomy of Peptococcus glycinophilus (Cardon and Barker 1946) Douglas 1957 with Peptostreptococcus micros (Prévot 1933) Smith 1957 and electrophoretic differentiation of Peptostreptococcus micros from Peptococcus magnus (Prévot 1933) Holdeman and Moore 1972. Int J Syst Bacteriol 1983; 33: 207210 .

12. Hare $\mathbf{R}$. The anaerobic cocci. In: Waterson AP (ed) Recent advances in medical microbiology. London, $\mathbf{J}$ \& $\mathbf{A}$ Churchill Ltd. 1967: 284-317.

13. Feltham RKA, Power AK, Pell PA, Sneath PHA. A simple method for storage of bacteria at $-76^{\circ} \mathrm{C}$. $J$ Appl Bacteriol $1978 ; 44: 313-316$.

14. Sutter VL, Finegold SM. Antibiotic disc susceptibility tests for rapid presumptive identification of gram-negative anaerobic bacilli. Appl Microbiol 1971; 21 : 13-20.

15. Watt B, Young O, McCurdy G. The susceptibility of anaerobic cocci from clinical samples to six antimicrobial agents. $J$ Infect 1979; 1 : 143-149.

16. Wren MWD, Eldon CP, Dakin GH. Novobiocin and the differentiation of peptococci and peptostreptococci. $J$ Clin Path 1977; 30: 620-622.

17. Watt B, Jack EP. What are anaerobic cocci? J Med Microbiol 1977; 10: 461-468. 
18. Holdeman LV, Cato EP, Moore WEC. Anaerobe laboratory manual, 4th edn. Blacksburg, VA, Virginia Polytechnic Institute and State University 1977.

19. Cowan ST. Cowan and Steel's Manual for the identification of medical bacteria, 2nd edn. Cambridge, Cambridge University Press. 1974

20. Gargan RA, Phillips I. A comparison of three methods for the transport of clinical specimens containing anaerobes. Med Lab Sci 1979; 36: 159-169.
21. Jackman PJH, Feltham RKA, Sneath PHA. A program in BASIC for numerical taxonomy of micro-organisms based on electrophoretic protein patterns. Microbiol Lett 1983; 23: 87-98.

22. Sneath PHA, Sokal RR. Numerical taxonomy. San Francisco, W H Freeman. 1973.

23. Smith GLF, Cumming CG, Ross PW. Analysis of EDTAsoluble cell surface components of gram-positive anaerobic cocci. J Gen Microbiol 1986; 132: 1591-1597. 